\title{
Rhetoric Patterns of Toulmin in Class Discussion Arguments Universitas Negeri Malang
}

\author{
Eva Eri Dia*, Suyono, Widodo HS., Sunaryo HS.
}

Universitas Negeri Malang, Indonesia

Received October 6, 2020; Revised December 10, 2020; Accepted December 20, 2020

\section{Cite This Paper in the following Citation Styles}

(a): [1] Eva Eri Dia, Suyono, Widodo Hs., Sunaryo HS. , "Rhetoric Patterns of Toulmin in Class Discussion Arguments Universitas Negeri Malang," Universal Journal of Educational Research, Vol. 8, No. 12B, pp. 8514-8527, 2020. DOI: 10.13189/ujer.2020.082662.

(b): Eva Eri Dia, Suyono, Widodo Hs., Sunaryo HS. (2020). Rhetoric Patterns of Toulmin in Class Discussion Arguments Universitas Negeri Malang. Universal Journal of Educational Research, 8(12B), 8514-8527. DOI: 10.13189/ujer.2020.082662.

Copyright $\odot 2020$ by authors, all rights reserved. Authors agree that this article remains permanently open access under the terms of the Creative Commons Attribution License 4.0 International License

\begin{abstract}
Rhetoric patterns in class discussions are described according to the following categories: (1) reasoning patterns in class discussions, and (2) argument patterns in class discussions. Reasoning patterns in class discussion have types of reasoning in the form of inductive reasoning patterns, deductive reasoning patterns, and mixed reasoning patterns. The argument pattern in class discussion is divided into argument patterns in the form of Top Down, and reasoning patterns in the form of Bottom Up. The purpose of this study was to provide additional insight into how to use rhetoric in the learning process in the form of class discussions and question-and-answer lectures by reviewing reasoning patterns and arguing patterns. The method used was descriptive qualitative with the researcher as the key instrument. The results of the research found that there was a pattern of reasoning that had six elements, namely data, stance, basic truth, support, modality, and rebuttal, which contained full, half rhetorical patterns and a little rhetoric, while the argumentation patterns found patterns of top dawn and bottom up. There is a benefit to students in which this study provides knowledge in conveying ideas, it is necessary to pay attention to vocabulary mastery (diction) and the suitability of the topic of conversation in order to have factual compatibility.
\end{abstract}

Keywords Rhetoric Pattern, Reasoning, Argumentation, Class Discussion

\section{Introduction}

Discussion is one of the ways to convey the arguments. Cummings (1999: 192-193) asserts that humans have their own awareness in thinking. The idea of the human mind is a reflection of various deep considerations in the form of verbal and nonverbal language. Verbal language is widely used by humans as a form of communicative humanity, one of which is speaking as a skill that must be in life (Saldaria, 2019: 20-27).

This is consistent with Suparno (2007: 1-7) who argues that speaking activities are self-expression, mental motor skills, symbolic processes, productive language skills, which occur in the context of space and time. Tarigan (2008: 22-23) divides the area of speaking into speaking as art and speaking as science. The art of speaking is often referred to as rhetoric. Rhetoric is the art of speaking skills that a person has in expressing ideas (Cock, 2020). It is in line with Syafi'ie (1988: 4-7) who argues that the characteristic of rhetoric is the domens of ethics, namely paying attention to ethics in the communication process. Golden (1984: 13) states that rhetorical studies are related to human relations with freedom in making choices for good things. According to Poespoprodjo (1999: 62-64) in rhetoric, there is a need for accuracy, in this case, the accuracy of thinking that is formed into words.

In relation to the four previous researchers, the need for rhetoric research in education has not been carried out in relation to the science of rhetoric which has a close relationship with dialectics. Through dialectics, people 
can learn about problems, put forward arguments, and organize logical thoughts (Hedrikus, 1991: 14). Dialectics in learning discussions in classrooms of Richmond, Wrench, and Gorham (in Irianta, (2014: 18) explain that conceptually learning communication is generally studied through two main paradigms, namely the rhetorical paradigm and the relational paradigm. Lee (1993) explains how Aristotle shows three things that need attention in communicating are the speaker, the subject as a message, and the audience who is listening (Iriantara, 2014: 16).

Discussion in learning is not merely functions as a communication medium to teach science, but it also aims to teach students to socialize, motivate, cultivate, and integrate (Effendy, 1988: 27-28). This activity at each level of education has different characteristics. This is due to the heterogeneity of the speakers. Discussions are applied to universities and it is inseparable from the role of lecturers in class management in the learning process. Class discussion activities were chosen by the lecturer to train students in critical thinking. Critical thinking of undergraduate and postgraduate students has a significant difference. In undergraduate students (S1), the discussion used is still limited to speaking skills that meet the standards, namely being able to ask and answer. In postgraduate education (S2), it has its own peculiarities and uniqueness that creates the ability to speak intelligently, S2 students are seen as being able to use the art of speaking or rhetoric in class discussion activities.

The language used in the learning process has unique characteristics. Good classroom learning activities will certainly carry out dialogical activities in interaction using multidirectional conversations, both between students and student-lecturers. In this regard, the lecturer chose discussion as a learning method to hone critical thinking skills. The rhetorical problem in the discussion was the main point in this study because in this study, the rhetoric characteristics of undergraduate and postgraduate students were found, namely in the form of telling activities that try to solve problems through a process of question and answer, providing information, and justification between presenters, discussion participants, and lecturers. It is in line as conveyed by Hendrikus (1991: 96-97), the question-and-answer process in the discussion provides answers to questions or serious discussions about an objective problem that the problem is discussed in small and large groups.

Eggen \& Kauchak (2012: 163) confirm that sometimes the discussion activities become ineffective due to there are several obstacles, namely the lack of initial knowledge, open or aggressive discussion participants may have a tendency to dominate the discussion, and discussion participants who are shy or unsure of themselves will withdraw and pay no attention, and lack of clear direction can be obstacles to effective discussion. In connection with Eggen \& Kauchak who have explained, Rogers (2003: 191) explained that there are two causes of fear during a question and answer session in a discussion. First, because the speaker doesn't like question and answer sessions. Second, there are speakers who like question and answer sessions. To be able to ask and answer questions, it takes techniques, strategies, proper procedures, and expertise in conveying it (Rogers, 2003: 192-200).

Class discussion in university involves speaking skills or the art of speaking students. Class discussion is a speaking activity that carried out with the aim of (1) seeking scientific truth, and (2) increasing the quality of truth. The discussion is divided into several sessions, namely presentations from the presenter, questions and answers, and conclusions. A question-and-answer session occurs between the presenter and discussion participants to discuss a problem. In asking questions, discussion participants use various forms of questions and forms of questioning. Likewise, with the presenter, in providing information on questions to discussion participants, the presenter uses various forms of reasoning and argumentation. Thus, this study was aimed to describe the patterns of reasoning and arguing in class discussions that will benefit the development of the Toulmin model of rhetoric studies, namely the pattern of reasoning including data, convictions, basic truths, support, modalities, and arguments and argumentation patterns are found.

\section{Rhetoric}

Rhetoric is the art of speaking. As stated by King (2008), speaking requires art to be accepted by listeners. It takes some special tricks in conveying opinions and ideas (Wintgens, 1993). Rhetoric is also closely related to the speaking ability of someone who is born or is a talent or talent (Hendrikus, 1991: 14). It is in line with King and Hendrikus, Keraf (2002, 1-3) who explain that rhetoric is a technique of using language which is included in the art of speaking which is based on a well-structured knowledge to influence people's attitudes and feelings.

Ratna (2009: 38-48) reveals that rhetoric has slow development like stylistics. In line with Ratna, Oka and Basuki (1990: 33-37) describe the deviation of the meaning of rhetoric with literary studies that focus on the use of language style and diction, as well as rhetoric deviations with composing guidelines, and prowess in arguing.

Rhetoric is a technique of using language as an art, which is based on a well-structured knowledge (Keraf, 2002: 1). Keraf further explains that the rhetorical aspect consists of (1) knowledge of language and the use of language properly and (2) knowledge of certain objects that will be conveyed in that language.

Based on a pragmatic viewpoint, Leech (1993: 22-24) defines rhetoric as the study of the effective use of language in communication. Wallace in Syafi'ie (1988: 4-6) details the main elements of rhetoric, namely: (1) good rationality, (2) ethics and moral values, (3) language, 
and (4) knowledge.

\section{Reasoning and Argument}

Warnick and Inch (in Dawud 1994: 26) explain that reasoning as an element of argument. The elements of argument consist of claims, reasoning, and evidence. Reasoning is the process of constructing a rational relationship between evidence and convictions to obtain conclusions.

An argument is a set of statements in the form of stance and support for it (Plantin, 2020). Arguments are used to influence other people to agree with them (Burnette, 2020). In argumentation, there is a structure that is widely used by speakers (Danisch, 2020). The characteristics of argument markers can be seen from three things. First, the position expressed the conclusion that the speaker wants to be accepted by the speaker. Second, evidence, namely objectively observable facts or conditions, beliefs or statements that have generally been accepted as true, or conclusions that have been previously established. This stance is supported by evidence and reasoning connecting the two. Third, an attempt to influence others means that speakers try to convince speakers of the truth or error that they are uttering.

Therefore, to analyze the argumentation, Top-Down and Bottom-Up analysis is used (Harmowati, 2013). Top-Down is a dialogue process that is used in the idea of argumentation. Bottom-Up is a monologue process used in the idea of argumentation, characterized by the existence of a problem / claim / sub-claim, it is followed by justification / justification, and ending with induction. This monologue process will show the integration of each part in the argumentation text. In relation to the rhetorical pattern, the Toulmin model is used to explicitly analyze the level of inference based on the truth made by the speakers. The Toulmin model consists of six elements, namely (1) data or basis, (2) establishment, (3) truth base, (4) support, (5) modality, and (6) refutation (Toulmin, Rieke, and Janik 1979) . Data have function as the basis for forming the stance. Data or basis are the same as evidence or facts or conditions that can be objectively observed factually, beliefs or premises that have been accepted as true, or conclusions that have been previously established. Stance is defined as an opinion or conclusion expressed by the speaker so that his speech partner will accept it. The basis of truth is in the form of rules, principles, or agreements in certain fields. The basis of truth is a component of reasoning that used to relate data to convictions. The support is a fact or conclusion that is used to support or validate the principles stated in the basis of truth. The modalities are phrases that indicate the type and level of strength of the basic truth. The modality has function to strengthen and show the validity of the condition. Rebuttal is an extraordinary situation or an unconfirmation that can destroy the basis of truth. By putting forward the refutation, the stance that used becomes more specific and the reasoning becomes stronger.

Based on these six elements, the Model of Toulmin is described into six types of patterns, namely:

1) Type I: data / basis and establishment, namely simple reasoning patterns. The stance which is at the same time as a conclusion rests on a data / basis. The relationship between establishment and data / basis must be relevant.

2) Type II: data / basis, stance, basis of truth, namely the pattern of reasoning I which rests on the basis of certain truths. The basis of truth as a foundation can be in the form of rules, propositions, or principles.

3) Type III: data / basis, stance, basis of truth, and support, namely reasoning that uses certain truth bases will be stronger if it gets support or reinforcement. Support can be in the form of observations, research, or experiences that have been proven to be true.

4) Type IV: data / basis, stance, basis of truth, support and modality, namely the level of certainty in the establishment of a reasoning can vary. The level of certainty of establishment depends on the strength of the data / basis, the basis of truth, and the support used as the foundation of the establishment. The stronger the foundation of the establishment, the higher the level of certainty of the establishment. The level of certainty can be determined by paying attention to adverbial words or phrases that connect the data / basis to the establishment.

5) Type V: data / basis, stance, basis of truth, support, modalities, and refutation. Refutation functions as a barrier to the scope of establishment. The scope of the establishment or conclusion depends on the existence or absence of the thing or condition that limit it.

\section{Research Method}

In this study, researchers used qualitative research with the aim of obtaining an explanation of a theory and the laws of reality using data in the form of coded sentence quotations which were then discussed in detail using the theory that had been found.

This study used a qualitative approach using inductive thinking. This is in accordance with the explanation (Creswell, 2013: 27-28) that qualitative research in their methodology has inductive characteristics that come from the researcher's experience in collecting and analyzing data.

In this study, researchers acted as a key instrument for collecting data. As a key instrument, in every process of obtaining data sources, the researcher is always presenting in the class where the class discussion takes place. The researcher acts as a full observer. The results of 
observations were recorded in field notes. This field note contains (1) observational background notes, (2) descriptive notes, (3) reflective notes. Observation background notes contain the day, date, and place / class where the discussion was held. Descriptive notes contain objective descriptions of specific events according to the focus of the study that cannot be captured by the recorder. Reflective notes contain thoughts, interpretations, or comments about what is observed from descriptive notes.

This study took data that related to rhetoric tools and rhetoric patterns of students at Universitas Negeri Malang. The subjects of this study were undergraduate and postgraduate students from all majors. Students conducted dialogues in class discussions between presenters and discussion participants. This determination was based on the consideration that each generation had the characteristics of different levels of thinking and reasoning, and the way of conveying ideas had different styles so that it can raise the phenomena related to the use of rhetoric.

The research data were in the form of verbal data. The data were in the form of students' speech who presented their roles as presenters and discussion participants, as well as lecturers who provided responses to the results of the discussion. The discussion activity indicated to contain rhetoric that included of: (1) rhetoric tools which include logic, language style, and ethics, (2) rhetoric patterns which include reasoning patterns and argumentation patterns, and (3) rhetorical strategies.

The data source of this study was in the form of speech from lecturers and students in class discussions. The speech was the form of interactive dialogue in class discussion presentations and question and answer sessions between lecturers and students, students and students, in lecture activities.

This data collection was carried out through the observation and documentation techniques. The observation technique was carried out to pay attention to the discussion phenomenon in the classroom, in this case, the researcher acted as a non-participant / observer as a participant. The researcher was an outsider of the group being researched, only watching and making field notes from a distance. Researcher was not directly involved with class discussion activities.

In the documentation technique, the researcher carried out the recording process during the discussion taking place in a question and answer session in each discussion. This recording process used a type of voice recording. Determining the type of recording was undertaken to maintain a normal class discussion atmosphere without being disturbed by the presence of the researcher.

\section{Research Instruments}

The research design of this study used qualitative research, thus, the researcher acted as the main instrument
(Bogdan Biklen, 1982: 27). This is reinforced by the opinion of Licoln \& Guba (1985: 192) which explains that researchers as humans are considered to have a number of advantages that are relied on for data collection and analysis. However, for a systematic framework, a set of guiding instruments is prepared for each stage of its implementation. The stages of data corpus analysis were carried out in this study and it included: (1) coding and data reduction, (2) data analysis, (3) inference and verification. Then the guiding instrument prepared includes: (1) data corpus codification guide, (2) data corpus analysis guide, and (3) inference guide.

\section{Data analysis technique}

Analyzing data in this study were based on the opinion of Crewell (2015: 251) which stated that data analysis in qualitative research consists of three stages, namely preparing and organizing data, reducing data, and presenting data. These three stages are the main elements of qualitative research. Apart from these elements, this study had development in accordance with the characteristics of the data that has obtained. Researcher was based on Creswell's opinion in using spiritual data analysis to process the data in this study. The following was the stages in this study (1) organizing the data, (2) reading and making memos (3) describing, classifying and coding the data (4) interpreting the data (5) presenting the data.

\section{Finding and Discussion}

Rhetoric patterns in class discussions are described according to the following categories: (1) reasoning patterns in class discussions, and (2) arguing patterns in class discussions. Reasoning patterns in class discussions have types of reasoning in the form of insuctive reasoning patterns, deductive reasoning patterns, and mixed reasoning patterns. The argumentation pattern in class discussion is divided into argument patterns in the Top Down form, and reasoning patterns in the form of Bottom Up. The rhetoric patterns of class discussion can be detailed as follows.

\section{Reasoning Patterns in Class Discussion}

\section{Reasoning Patterns of Induction}

The reasoning model is a general description of the structure, style, or pattern of reasoning (argument). Reasoning using the Toulmin model consists of six elements, namely (1) data or basis, (2) stance, (3) basic truth, (4) support, (5) modality, and (6) refutation (Toumlin, Rieke, and Janik 1979). Based on these six elements, the Toulmin model can be described into five types of patterns, namely: type I, which includes data or 
basic and establishment elements, type II includes basic elements, establishment and basis of truth, type III includes basic, stance, basic truth, and support, type IV includes the basis, stance, basis of truth, support, and modality, and type $\mathrm{V}$ includes the basis, stance, basis of truth, support, modality, and rebuttal.

Each type proposed by Toulmin must be sorted according to the order of the elements previously described. If reasoning has elements that are random or not in accordance with the existing type of pattern, the researcher will classify it with a different type name. Providing this type name will later adjust to the previous type name. The last name for the Toulmin type is "type V", so that the next type will be named with type VI, VII, and so on.

The speech in class discussion activities contained in the selected data is as follows:

\section{Form: Data or Basic:}

Regarding the topic of our paper at this, namely (unclear) proper education in Indonesia, which with the development of science and technology, then a nation with dignity and the human being aspired to and the repitalization of education based on the development of science and technology which continues to advance demands the development of society as a whole.

(Pen.Dsr.S3.H3204)

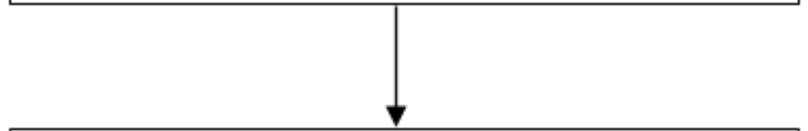

\section{Form: rebuttal}

The most effective way is through education, while to become a nation with dignity, the Indonesian nation must strengthen (unclear) the nation's political institutions, economic institutions, technological institutions, legal institutions, ethical institutions, social institutions and cultural institutions. Meanwhile, the aspirated Indonesian human being based on the repetalization of education through proper learning is that the first human being must have high sensitivity, the second is great independence and has a solid responsibility. (Pen.Dkg.S3.H3204)

Data 1. Inductive Reasoning Pattern Chart

Context: it is explained by the moderator when giving an introductory sentence before entering into the discussion will be explained, and also providing an explanation of the most effective way of dealing with the themes that have been previously discussed, namely the development of science and technology.

Based on data 1, it can be explained that according to (Toulmin, 1979) which states the elements of reasoning consist of six, including (1) data or basis, (2) establishment, (3) truth base, (4) support, (5) modality , and (6) refutation. So, data of number 1 . contain two elements, namely data or basic elements, and elements of support. Data or basis (Pen.Dsr.S3.H3204) data or basic elements in the pattern of reasoning indicate that there is evidence or conditions that can be factually observed objectively. The moderator explains with the sentence "the proper education in Indonesia, the development of science and technology can make the Indonesian nation more dignified, achieve the revitalization of education and achieve the aspirations of society”.

The moderator's speech has the first series of discussions on the topic of discussion material in the form of education in Indonesia and the development of science and technology. The subsequent narrative discusses the conclusion from the previous speech that the development of science and technology requires the development of society as a whole. This series shows that there is an appropriate continuity between the utterances at the beginning of the sentence with the next sentence.

The data (Pen.Dkg.S3.H3204) of the refutation in the pattern of reasoning show that there is a rebuttal in the second sentence regarding the narrative in the previous sentence. The first sentence discusses about the importance of education in the achievement of mastery of science and technology. In the second sentence, there is a rebuttal, namely "Meanwhile, Indonesian people who are aspired to be based on repetalization of education through proper learning, namely the first human being must have a high sensitivity, the second is great independence and has a solid responsibility."

The moderator has a series of stories starting from the provision of some facts or current conditions regarding the material that has been discussed by the presenter in the form of a discussion of educational issues that must be achieved and ways to achieve a dignified nation. The following speech is about the refutation of the previous speech that what should be prioritized is high sensitivity and great independence, not about education.

As it has been explained by the moderator's speech, if it is categorized in the type of reasoning, then the moderator's speech above belongs to the type of inductive reasoning. This can be seen from the general conclusions at the end of the paragraph in the form of: Whereas Indonesian people who are aspired to be based on the repetalization of education through proper learning, namely the first human being must have high sensitivity, the second is great independence and has solid responsibility.

In data 1 , the elements that can be found are data or bases and rebuttals. If it is viewed from the theory (Toulmin, 1979), the data are not included in one type of Toulmin, so the researcher creates a new type that is different from the previous Toulmin type. The type that the researcher has been found was included in the TYPE VI reasoning pattern category. These data do not agree 
with Toulmin's theory. In the data found, namely data or basics, and it is followed by rebuttals, this series is certainly not in accordance with the series of pattern types that exist in the Toulmin theory.

In accordance with the name that given to the data as the TYPE VI reasoning pattern, data 1 are declared to appear and stand alone without following the theory used by researcher as the main guideline in analyzing data. The TYPE VI reasoning pattern itself is a type pattern that contains data or basic elements and rebuttals, namely a simple reasoning pattern due to its few elements, but it is complicated because of its random and irregular pattern.

Data 1 in the moderator's speech above have two elements from the six elements suggested by (Toulmin,
Rieke, and Janik 1979). This data can be said to be $a$ bit of rhetoric because it merely includes two elements, namely the basic element and the element of refutation. This datum does not contain other elements such as stance, justification, support and modalities.

\section{Deductive Reasoning Patterns}

Another type of reasoning that exists in reasoning patterns is deductive reasoning. Deductive reasoning starts from general knowledge leading to new knowledge about individuals in particular which we base on general knowledge (Syafi'ie, 1988: 191). For example, consider the following deductive reasoning data:

Form: Data or Basics

"First, I will explain about the development of pleirialism, if the origin itself comes from perennialism taken from the word perennial which means (unclear). Because Aristotle considers that existing education needs to go back to the past based on the belief that belief is useful for us today. " (Pen.Dsr.S2.H2205)

Form: Modality

"Thus, the values according to him, it is not appropriate yet, so he adjusts the guidelines in Christian teachings. That's why in his day it is known as Neo-Thomism (unclear)" (Pen.Md1.S2.H2205)

Form of Rebuttal:

"Meanwhile, accidents are special circumstances that can change and are less important than essential. For example, I like singing or my passion for reading. Then the role of the teacher in these students is not just an intermediary, if according to perennialism the teacher is not only the intermediary, they are also as students. And as students who learn while teaching and doing morals (unclear) such as teaching positive moral characters to each student." (Sgh.S2.H2205)

Data 2. Deductive Reasoning Patterns Chart 
Context: the presenter's speech during a class discussion. This speech is about giving some examples of the problems that raised in the class discussion on that day.

Based on data 2, it can be explained that according to (Toulmin, 1979) which asserts that the elements of reasoning consist of six, including (1) data or basis, (2) establishment, (3) truth base, (4) support, (5) modality , and (6) refutation. So, data of number 2 contain three elements, namely data or basic elements, modalities, and elements of rebuttal. The data or basis (Pen.Dsr.S2.H2205)have a pattern of reasoning which indicates that the data that discussed are the starting point for providing material in class discussions about preiliarism which will later become the initial foundation when class discussions occur. These are basic datafor the class discussions to be carried out. The basic data will then be followed by a speech in the form of a modality.

The presenter has a series of stories starting from an explanation of the development of pleirialism, from the origin of the word to the meaning of the word itself. The presenter also discusses Aristotle's character who thinks about education in the present. The first sentence and the second sentence basically have similarities, namely both express speech in the form of a conclusion. In the second sentence, the character is more to add to the conclusion in the first sentence.

The reasoning pattern in the modality element (Pen.Mdl.S2.H2205) indicates that there is reinforcement in the data or basis that has been previously presented. This modality aims to strengthen the arguments presented so that the audiences or listeners better understand and understand the material of the class discussion that is taking place. The modality element also plays an important role in strengthening the reasoning spoken by the presenter. The presenter has a series of stories which begins with the provision of a summary of values which is continued with a discussion of the reasons for giving the name Neo-Thomism. In general, this speech can be seen as a causal form of speech.

The reasoning pattern in the element of rebuttal (Pen.Sgh.S2.H2205) shows that there is a form of contradiction which is referred to the presenter regarding the difference between accidents and essences. This is in the keyword 'while' which is at the beginning of the sentence. At the end of the sentence, it can be seen that the presenter tries to strengthen his opinion by adding examples of problems to students who carry out learning activities accompanied by teaching activities. The presenter has a series of utterances in the form of understanding material about the accident followed by examples. The presenter also provides a discussion about the role of the teacher which ends with the students' assignments.
Data 2, it is seen from the form of the speech which included in the type of deductive reasoning because the expressing must include the statements that are general in nature and then converge on statements that are specific in nature. In everyday life, we often use deductive reasoning by using general truths that we accept as proven truths. We rarely question the truth anymore, for example we believe in the truth that the earth revolves around the sun. As the same example was told by the presenter in data 2, namely, the values which according to him were not suitable, he adjusted the guidelines in Christian teachings. Therefore, in his day it was known as Neo-Thomism.

The data in speech 2 above have three of the six elements proposed by (Toulmin, Rieke and Janik 1979). This data can be mentioned to be a form of semi-rhetoric because it only includes three elements, namely the basic element or data, the modality element and the basic element of refutation. This datum does not have other elements such as opinion, justification, and support. The data cannot be said to meet the criteria for data that has full rhetoric.

In moderator on data 2, the elements that can be found are data or basis, modality, and rebuttal. When it is viewed from the theory (Toulmin, 1979), the data are not included in the Toulmin type category. This datum stands alone by generating three random elements. These elements include basis, modality, and rebuttal. Data number 2 is included in the category of TYPE VII reasoning pattern, because there is no match for Toulmin's type. The patented TYPE VII reasoning pattern has elements in the form of a basis, modality, and ends with elements of refutation.

\section{The Pattern of Argument in Class Discussion}

Dawud (1994: 26) explains reasoning as an element of argument. An argument is a set of statements in the form of a stand and support for it. Argumentation analysis can be done with Top-Down and Bottom-Up analysis (Harmowati, 2013).

\section{Top Down}

Top Down is a dialogue process that used in the idea of argumentation. The composition of the elements of the dialogue process is as follows: Introduction, problems, solutions, evaluation, and conclusions (Harmowati, 2013). The existence of this composition is to construct an argumentation text that shows an understanding of the meaning of a text. Top Down is one of the ways that can be used in analyzing an argument. Consider the following examples of data analysis for the Top Down argumentation: 
Evaluation: Okay... that was a presentation from our group. Then the third meeting was about "Ethics in Role" I think that's an explanation from us where we have to understand research and non-research. (Arg.TD/Ev1.S2.H3104)

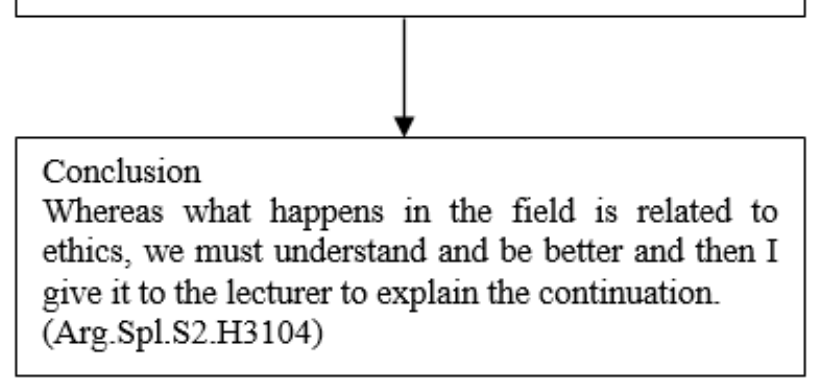

Data 3. Argument Pattern Chart of Top Down

Context: it is expressed by the moderator when the person has finished in carrying out the class presentation. The moderator closes the discussion with a few conclusions.

The Top Down argumentation pattern on data 3 has two elements, namely the evaluation element and the conclusion element. According to (Toulmin, 1979) the Top Down, argumentation pattern has five sets of elements that make a speech complex and perfect. The five series cover: introduction, problem, solution, evaluation and conclusion. Even though data 3 do not meet all of the elements put forward by Toulmin, the data still categorized into the Top Down category.

Based on the data above, there are two argumentations of Top Down and it is found in the moderator's speech, namely evaluation and conclusion. Evaluation (Arg.Evl.S2.H3104) the pattern of argument shows that the moderator evaluates as the final result of the class discussion that has been completed by revealing the closing sentence and mentioning a little about research and non-research on the discussion.

The argumentation pattern in the conclusion element (Arg.Spl.S2.H3104) points out that the moderator is concluding the results of the class discussion that has been carried out. This conclusion can be seen from the moderator's speech which shows the final result of the discussion, the moderator's speech argues that the one who took part in the class discussion that day must be able to understand and become better in the future in mastery of ethics in the field.

The data in the speech 3 above have two elements from the five elements having been stated by (Harmowati, 2013). This data can be said to be a bit rhetorical because it merely includes two elements, namely evaluation and conclusion elements. This datum does not have other elements such as introduction, problems and solutions. This datum cannot be said to meet the criteria for data that has full rhetoric.

Based on these data, there are two argumentations of Top Down found in the moderator's speech, namely the evaluation and conclusion elements. Evaluation (Arg.Evl.S2.DAA) the pattern of the argument shows that the moderator attempts to close the class discussion activities by telling the audience that group 8 , as the group that progresses the presentation, has finished doing its job. Finally, the moderator would like to thank the audience for being willing to pay attention. Conclusion (Arg.Spl.S2.DAA) The pattern of argument shows that there is a delivery of conclusions from the moderator regarding the presentation material that has been discussed previously. The conclusion is about the OIC and its objectives.

The moderator is the leader in a discussion, one of which is a class discussion. The manner and style of leading play a very decisive role in the discussion. The discussion leader must be flexible in playing its role, because on the one side, the moderator is in charge of leading and directing the discussion, but on the other hand, the person is an equal partner of the participants who can contribute thoughts and opinions (Hendrikus, 1991: 103).

The moderator in speaking to the data 3 above has fulfilled and carried out the main duties of a discussion leader appropriately. This can be seen from how the moderator provides a closing utterance in the form of evaluations and conclusions from the results of the class discussions that have taken place. The evaluation in the moderator's speech is more of a slight evaluation in the form of a class discussion closing sentence and notification to discussion participants about the material that will be conveyed at the next meeting, namely material about ethics in play. At the end of the sentence in the speech, the moderator gives a closing sentence that the presentation at that time has been completed, and is continued with the moderator's opinion that the discussion participants must understand research and non-research.

The data in the above speech have two elements from the five elements suggested by (Harmowati, 2013). This data can be said to be a bit rhetorical due to it only includes two elements, namely evaluation and conclusion elements. This datum does not have other elements such as introduction, problems and solutions. This datum cannot be said to meet the criteria for data that have full rhetoric. Another example can be seen in the following chart: 
Introduction

The importance of the formulation of an appropriate education policy in Indonesia, there are three major points that we can take in this discussion, the first is the development of science and technology in education, then the second is education and national dignity, then the third is (unclear) that the new Indonesian people aspire to (unclear) education. (Arg.Pgt.S3.H3204)

\section{Problem}

Let us begin to discuss the development of science and technology in education that related to the role of science and technology in the development of social society. We can see that science and technology has many effects, many influences if we talk about science and technology, it cannot be separated from the accompanying influence on society.

(Arg.Msl.S3.H3204)

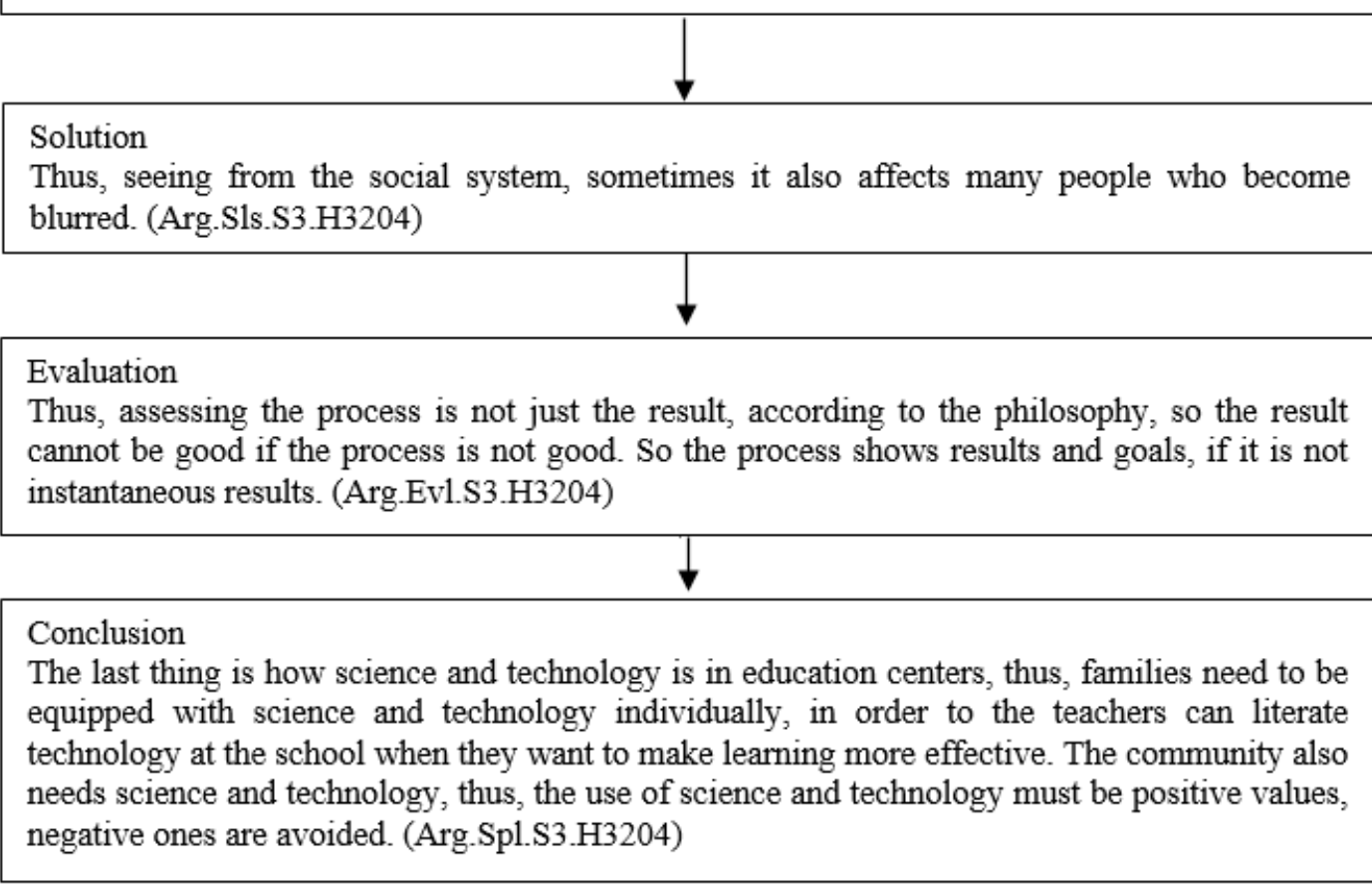

Data 4. Top Down Reasoning Pattern Chart

Context: it is explained by the presenter in providing class discussion material, providing solutions to problems in the discussion, providing an evaluation of the problems that has been previously discussed.

Based on the data of 4 above, there are five Top Down arguments having been found in the presenter's speech, namely introduction, problem, solution, evaluation, conclusion. The introductory element (Arg.Pgt.S2.H3204) has an argumentation pattern which shows that the presenter provides an introduction in the prefix to a class discussion which leads to the material importance of policy formulation in education. The presenter also briefly explains that three points will be discussed in the class discussion on that day. The presenter has a series of speeches that begin with persuasive sentences about the importance of education policy formulation, then it is proceed with providing discussion material in the form of three basic points.
The argument pattern on the element of problem (Arg.Msl.S2.H3204) indicates that the presenter gives a problem in his argument which was previously preceded by a persuasive sentence. The persuasive sentence is in the form of an invitation to discuss the development of science and technology. Then this speech is continued with the disclosure of the problem in the discussion material in the form of the influence of science and technology that cannot be separated from the community.

The element of solution (Arg.Sls.S2.H3204) has an argumentation pattern which indicates that the presenter is trying to provide a solution to the problem in the class discussion in the form of an argument to see first the social system that is likely to be affected by the problem being discussed. The evaluation (Arg.S2.S2.H3204) of the argumentation pattern shown by the presenter is in the form of an evaluation of the results of providing solutions to problems that exist in the discussion material. This 
evaluation is in the form of providing knowledge that the results obtained and it will not be satisfactory if the process alone is unhealthy and incomplete. The presenter also concludes that the process that has been carried out, whether it is a healthy or unhealthy process, will determine what the results will be.

The argumentation pattern on the impulse element (Arg.Spl.S2.H3204) shows that the presenter tries to provide conclusions from the results of the discussions that have been carried out previously. The conclusion is in the form of a family that must be provided with knowledge on the science and technology sector. Teachers and the community must also have the science and technology material provisions. The presenter has a series of stories starting from explaining the condition of science and technology in society, it is followed by discussing who should be provided with the science and technology material.

The data in the above speech have five elements from the five elements suggested by (Harmowati, 2013). These data can be said to be a form of 'full rhetoric' because it has fulfilled all the elements in the Top Down section of the argumentation material. This element includes elements of introduction, problem, solution, evaluation, and conclusion. Examine other examples of argumentation patterns below:

\section{Introduction}

Okay here, let's to talk about school (it is not clear due to the voice is slow), others have a communication system, an organizational system, in essence the theoretic system. (Arg.Pgt.S2.H3205)

\section{Problem}

From several studies of this central curriculum, I have not been able to find the criteria to be included in a system what education itself is, the effect of educational organization,then how to control organization, evaluate to what extent is this organization as a school system program as a sociopolitical system so as not to be affected in the social life of education (Arg.Ms1.S2.H3205)

\section{Conclusion}

Because if we look at education socially, then there is nothing that we can take to be used in the question of what the power is. But it is directly to us to the point that we have that final task, Based on the explanations are given earlier, it can provide the final illustration (Arg.Spl.S2.H3205)

Data 5. Top Down Argument Pattern Chart
Context: it is spoken by the questioner at the time of expressing its question and then providing a conclusion to the question that will be asked.

In data 5 above, only three of the five elements proposed by Toulmin. The three elements are in the form of introductory, problem, and conclusion elements. The argument pattern in the introductory element (Arg.Pgt.S2.H3205) can be seen from how the questioner provides an introduction before giving the real question. The introduction is in the form of a school in which there is a communication system as an example.

The pattern of argumentation in the problem element (Arg.Msl.S2.H3205) can be seen from how the asker tries to try to ask the question which is the main problem in this matter. The problem is the questioner who has not found the criteria expressed by the presenter. In fact, the questioner felt that what was found did not match what was presented by the previous presenter. The pattern of argumentation in the element of conclusion (Arg.Spl.S2.H3205) can be seen from how the asker provides conclusions on the problem questions that have been previously raised. This conclusion is in the form of an illustration that can be used on facts in the environment.

The process of asking and answering in a class discussion is always an interesting session to be observed. Some of the questions that are raised and argued by the discussion participants have their own characteristics. The questions in data 5 above are included in the types of informative questions. Informative questions are those that require the smallest possible knowledge, experience, and basic materials. This question is intended only to obtain information or explanation (Hendrikus, 1991: 117). The data 5 suggest the asker's speech who wants to know information which according to the person is not in accordance with the facts that exist in everyday life, so that this has succeeded in making many possibilities that arise the facts presented by the presenter are in accordance with reality or indeed the presenter has facts from some unusual examples.

The data in the speech 5 above have three elements from the five elements stated by (Harmowati, 2013). This data can be said to be a form of half rhetoric because it merely includes three elements, namely elements of introduction, problem and conclusion. Thesedata do not have other elements such as solutions and evaluation. This means that these data cannot be said to meet the criteria of data which has the type of full rhetoric.

\section{Bottom Up}

Bottom Up is a monologue process that used in the idea of argumentation, characterized by problems, it is followed by justification, and it ends with induction (Harmowati: 2013). This process of monologue will show the integration of each part in the argumentation text. 


\section{Justification}

Thank you. Okay, the second question is immediately answered by our design group, determining the object to be taken the sample then determining the tool for sample research according to the number specified earlier. The second is doing a random sample of clarification. Please pay attention. This is done to divide into several or samples that reflect an increase in quality because the next element of the population is a random and non-random centric sample (Arg.Pbr.S2.H3104)

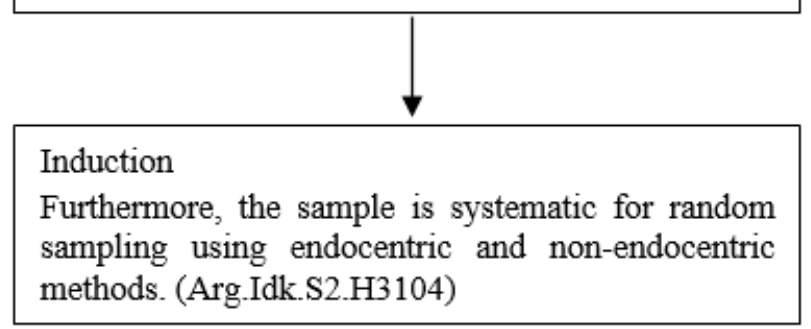

Data 6. Bottom Up Argument Pattern Chart

Context: it is uttered by the moderator when giving a conclusion from the answerers who have answered questions from the audience.

Based on the theory (Harmowati, 2013) which reveals that the Bottom Up argumentation pattern has a series of pattern elements in the form of: problem, justification, and induction. In data 6 above, two of the three elements are merely suggested by Harmowati. The two elements are in the form of problem elements and elements of justification. The argument pattern in the element of justification (Arg.Pbr.S2.H3104) shows that the moderator's speech contains elements of justification regarding the procedures for designing. The moderator attempts to justify the questioner's question as a form of clarification of the question that is proposed.

The moderator has a series of stories starting from gratitude to the questioner. This is undertaken as a form of appreciation for the moderator to the one who expresses the question. The activity is continued with notification that the questions asked will be answered directly by the presenter, namely the design group. The moderator in speaking also gives a few simple answers to the questions that have been expressed. The answer is in the form of determining the object to be sampled, then the second method is to do a clarification random sample. Finally, the moderator expresses with the intention of answering the question from the asker. Then it is proceeded with a request to the audience to pay attention to the answerer and the voice from the moderator.

The argumentation pattern in the element of induction (Arg.Idk.S2.H3104) on the data gives conclusions from the explanation on the previous element of justification. The conclusion made by the moderator can be seen through the keyword 'so'. The following sentence from the moderator shows that the lecturer invites the discussion participants to ask questions related to the problems and topics of the class discussion.

The data in the speech above, it has two elements from the three elements stated by (Harmowati, 2013). The data can be said to be a form of semi-rhetoric because it only includes two elements, namely the elements of justification and instruction. This data does not have an element of problem, which means that it cannot be said that it meets the criteria for data that have the type of full rhetoric. Another example of the Bottom Up argument is as follows:

\section{Problem}

The first (unclear) implication for the material and logistics is the role of teachers and students. Thus, the role of the teacher is defined during the teaching and learning process (Arg.Ms1.S3.H3204)

\section{Justification}

Hence it is not only the teacher who plays a role in the teaching and learning process, but students are also involved in the teaching and learning process where both of them have different roles, the teacher is to facilitate, while the students are learning.(Arg.Pbr.S3.H3204)

\section{Induction}

Then the fourth is the active experimental stage where they will experiment with what they have practiced in the learning process from what they have experienced, then, the students have active experiences there and then the students relate to the concept then they can do the experiment themselves from the learning process (Arg. Idk.S3.H3204)

Data 7. Bottom Up Argument Pattern Chart

Context: it is explained by the presenter in providing justification for the problems that exist in class discussion activities and then continuing to provide conclusions on the problems and justifications that have been discussed previously.

Based on the data 7 above, there are three arguments that found in the presenter's speech, namely problem, justification, and induction. influencing behavior that has been referred to as reflective. This material will later be the subject matter discussed by the presenter.

The element of justification (Arg.Pbr.S3.H3204) can be seen from the speech of the presenter who tries to provide justification for the problems that raised earlier. This justification is in the form of providing solutions, making reading activities and helping students when experiencing difficulties in learning activities.

The argumentation pattern in the element of induction 
(Arg.Idk.S2.H3204) can be seen from the speech of the presenter who attempts to provide conclusions on the discussion previously described. This element of induction also includes giving examples of actions undertaken by the teacher to help students to be more able to think ahead. The examples are giving material, giving stimulus-response, to the evaluation stage.

The data in the speech above, they have three elements from the three elements that revealed by (Harmowati, 2013). The data can be said to be a form of full rhetoric due to it covers all the elements. Pay attention to the following selected data:

\section{Problem}

Regarding to individual teaching, the requirements for teachers to understand the abilities of each student, then, the process of understanding encourages the teacher to teaches about interest, motivation, interest in the material to be taught. (Arg.Msl.S3.H3204)

\section{Justification}

This implies that we see from the students' interest in asking where, like what, we try to facilitate. Then, it will make teaching to be more effective. Then for evaluation, definitely, it cannot be different in meaning except in the assessment process. Thus, all of these can be answered by the students so they cannot go anywhere.

(Pbr.S3.H3204)

Data 8. Bottom Up Argument Pattern Chart

Context: it is spoken by the answerer in providing conclusions on the problems and justifications that have been discussed previously.

Based on the theory (Harmowati, 2013) which argues that the Bottom Up argumentation pattern has a series of pattern elements in the form of: problem, justification, and induction. In data 8 above, only two of the three elements are revealed by Harmowati. The two elements are in the form of problem elements and elements of justification. The problem (Arg.Msl.S3.H3204) pattern of argument is shown by the existence of answering speech that leads to give the problems before expressing the justification. The problems raised by the answerers are in the form of individual-based lessons. Another problem is the teacher's discussion of its duties at school.

The element of justification (Arg.Pbr.S3.H3204) has an argumentation pattern which is indicated by the existence of an answerer who attempts to answer the question from the asker. This justification contains solutions that can be used to solve previous problems. This speech also includes a summary of the answers that given by the answerers.
The data in speech 8 above have two elements from the three elements stated by (Harmowati, 2013). Thedata can be asserted to be a form of half rhetoric because they merely include elements of problem and justification.

The conclusion that can be drawn from the above explanation is that the data selected in the reasoning pattern contain data with induction and deduction reasoning patterns. The data have been chosen in the Top Down argumentation pattern, it is found data with a different pattern from the pattern proposed by Toulmin, 1979. The data were then given their own name by the researcher, namely with the names POLA VI, VII, VIII, and so on. The data selected in the Bottom Up argumentation pattern also found data with patterns that were not all the same as the theory of Harmowati 2013.

\section{Conclusions}

The pattern of reasoning had six elements including data or basis, conviction, truth base, support, modality and rebuttal. Dealing with the six data sample objects, the moderator, presenter, questioner, answerer, rebuttal, and lecturer were the objects. The six objects had a comprehensive rhetorical pattern. Some objects were categorized into 'full rhetoric', 'half rhetoric', and 'little rhetoric'. In relation to the argumentation pattern in the second research question, the argumentation pattern was divided into two forms, namely Top Down and Bottom Up. The argumentation of Top Down had five elements including: introduction, problem, solution, evaluation, and conclusion. The Bottom Up pattern had three elements, namely: problem, justification, and induction. Based on the six sample objects having been studied according to the Top Down and Bottom Up patterns, it also indicated that the six objects also had a comprehensive rhetorical pattern. Some objects were categorized into 'full rhetoric', 'half rhetoric' and 'a little rhetoric' according to the Toulmin model. Full rhetoric is interpreted as covering all elements of the model presented by Toulmin, rhetoric is partly interpreted because it only includes three elements, namely basic elements or data, modality elements and basic elements of rebuttal, while a little rhetoric means the model only includes two elements, namely basic elements and element of support.

\section{REFERENCES}

[1] Alisjahbana, S Takdir. 1969. New Grammar of Indonesian Language. Jakarta: Dian Rakyat.

[2] Anwar, Khoirul. 2010. Rhetorical Patterns of Research Articles in Language Teaching Journals. Dissertation. Malang: Universitas Negeri Malang.

[3] Artha, Arwan Tuti, 2002, Creating Grammatically Da’wah 
Language, Da'wah Journal, number 5, year III, July December, Yogyakarta: Da'wah Faculty IAIN Sunan Kalijaga.

[4] Bogdan, Robert C and Biklen, Sari Knopp. 1982. Qualitative Research for Education: An Introduction to Theory and Method. Boston: Allyn \& Bacon, Inc.

[5] Bogdan, R. dan Taylor, J.S. 1993. Basics of Qualitative Research. Translation by A.K. Afandi. Surabaya: National Business.

[6] Bormann, Ernest G. and Nancy C. Bormann. 1986. Rhetoric (An Integrated Approach). Fourth Edition. Jakarta: Erlangga Publisher.

[7] Buchanan, L.B. 2011. Discussion in the Elementary Classroom: How and Why Some Teacher Use Discussion. The Goergia Social Studies Journal Spring, 1 (1): 19-31.

[8] Chaer, Abdul. 2010. Language Unity. Jakarta: PT Asdi Mahasatya

[9] Cummings, Louise. 1999. Pragmatics: A Multidisciplinary Perspective. Yogyakarta: Learners’ Library.

[10] Churchill, Linsey. 1978. Questioning Strategies in Sociolinguistics. Rowley: Newbury House Publiser Inc.

[11] Clark, Herbert H. and Eve V. Clark. 1977. Psychology and Language: An Introduction to Pyscholinguistics. New York: Harcourt Brace and Jovanovich, Inc.

[12] Creswell, John W. 2015. Qualitative Research and Research Design: Selecting Among Five Choices. Translation. Edition 3. Yogyakarta: Learners’ Library.

[13] Daraini, Saadatud. 2009. The Analysis of Personification Language Style in Insomnia Short Story Compilation by Anton Kurnia. Downloaded from http://eprints.ums.ac.id/56 58/1/a310050063.PDF on Sunday, July 1, 2018

[14] Dawud. 1998. Reasoning in Indonesian Language Utterance of Elementary School Students. Dissertation. Malang: IKIP Malang

[15] Dardjowidjojo, Soenjono. 2012. Psycholinguistics (Introduction to Understanding Human Language). Jakarta: Foundation of Pustaka Obor Indonesia.

[16] Desak, Putu Eka Pratiwi. 2015. Commercial Bond of Electronic Media. Dissertation

[17] Dwi, Ningwang Agustin. 2013. Diction and Language Style in The Speech of President Soeharto. Research Articles

[18] Effendy, O.U. 1986. Communication Dynamics. Bandung: Remandja Karya.

[19] Eggen, Paul and Don Kauchak. 2012. Strategies and Models of Teachers: Teaching Content and Thinking Skills. Jakarta: PT Indeks.

[20] Elisabett, Apti Elita Sari. 2016. Language Style and Structure Feature The Journey of Intisari Magazine January Edition 2016. Undergraduate Thesis

[21] Golden, James L., dkk. 1984. The Rhetoric of Western Thought. Third Edition. Lowa: Kendall/Hunt.

[22] Harmowati. 2013. Rhetoric Pattern of Speech Manuscript of Grade X Students at State Senior High School 7 Bengkulu
City. Thesis. Bengkulu: Bengkulu University

[23] Harumi, Endah. 2008. Regent Speech Rhetoric in East Java Textual Approach. Dissertation. Malang: Universitas Negeri Malang.

[24] Hendrikus, Dori Wuwur. 1991. Rhetoric: Skillful in Speech, Discussion, Argumentation, and Negotiation. Yogyakarta: Kanisius.

[25] Ibrahim, Abd Syukur. 1993. Speech Act Study. Surabaya: Offset Printing Business

[26] Iriantara, Yosal. 2014. Learning Communication (Interaction, Communicative, and Educative in The Class). Bandung: Simbiosa Rekatama Media.

[27] Indriani, Indah Novita. 2017. Argumentation Reasoning in Written Passage of Grade IX Students at State Junior High School 8 Kediri. Downloaded from http://simki.unpkediri.a c.id/mahasiswa/file_artikel/2017/12.1.01.07.0043.pdf on Sunday, July 1, 2018

[28] Keraf, Gorys. 1981. Indonesian Language Grammar for Senior High School. Ende-Flores: Nusa Indah.

[29] Keraf, Gorys. 2002. Diction and Language Style. Jakarta: PT Gramedia Pustaka Utama.

[30] King, Larry. 2008. The Art of Talking to Anybody, Anytime, and Anywhere. Jakarta: PT Gramedia Pustaka Utama.

[31] Leech, Geoffrey. 1993. Pragmatics Principles. Translator: M.D.D. Oka. Jakarta: Indonesia University.

[32] Lincoln, Y.S. and Guba, E. G. 1985. Naturalistic Inquiry. Beverly Hills: Sage Publications.

[33] Maarif, Zainul. 2015. Rhetoric of Public Communication Method. Jakarta: PT Raja Grafindo Persada

[34] Mahanani, Arie Dhinar. 2004. Undergraduate Thesis: Mathematics Learning Experiment. Downloaded from http://digilib.uns.ac.id/dokumen/download/5566/MTY=/ana lisis-penalaran-pada-karangan-siswa-kelas-VIII-SMP-Negri -2-Tangen-Kabupaten-Sragen-tahun-ajaran-20062007-abstr ak.pdf on Sunday, July 1st, 2018.

[35] Mahsun. 2007. The Method of Language Research: Strategy Stages, Method, and The Techniques. Jakarta: PT Raja Grafindo Persada.

[36] Marta, Nengah. 2015. Rhetoric. Yogyakarta: Graha Ilmu

[37] Marta, Nengah. 2015. Rhetorics and Its Usage in Various Fields. Downloaded from https://ejournal.undiksha.ac.id/in dex.php/PRASI/article/download/6828/4675, on Sunday, July 1, 2018

[38] Mundiri. 2012. Logics. Jakarta: PT RajaGrafindo Persada.

[39] Mey, Jacob L. 1993. Pragmatics: An Introduction. Oxford: Blackwell Publishers.

[40] Miles, Matthew B., Huberman, A. Michael. 1992. Qualitative Data Analisys. California: Sage Publication, Inc.

[41] Moleong, J Lexy. 2005. Qualitative Research Methodology. Bandung: PT Remaja Rosdakarya.

[42] Moeliono, Anton and Soenjono Dardjowidjojo. 1988 Standard Grammar of Indonesian Language. Jakarta: 
Library Hall.

[43] Mubarok, Syaifudin. 2015. The Usage of Personification Language Style and Special Word in Poem Compilation When Love Speaks by Khalil Gibran. Downloaded from http://eprints.ums.ac.id/34884/1/NASKAH\%20PUBLIKAS I.pdf on Sunday, July 1, 2018

[44] Mujianto. 1998. Passage Rhetorics of Indonesian Language Scientific Speech. Dissertation. Malang: Universitas Negeri Malang

[45] Mundiri. 2012. Logics. Jakarta: Rajawali Pers.

[46] Narwaya, Tri Guntur. 2014. Phylosophy and Development and Communication Science. Downloaded from http://fikom.mercubuana-yogya.ac.id/wp-content/uploads/2 014/06/Filsafat-dan-Etika-Materi-Kuliah-Ke-2.doc on Sunday, July 1, 2018

[47] Pateda, Mansoer. 2010. Lexical Semantics. Jakarta: PT Rineka Cipta

[48] Poespoprodjo, W. 1999. Scientifics Logics: Introduction to Dialectics and Science. Bandung: Grafika Library.

[49] Ramlan. 1987. The Syntaxis of Indonesian Language Science. Yogyakarta: CV. Karyono.

[50] Ratna, Nyoman Kutha. 2009. Stylistics: The Study of Language Poetic, Literature, and Culture. Yogyakarta: Learners' Library.

[51] Rahardi, Kunjana. 2005. Pragmatics: Imperative Politeness of Indonesian Language. Jakarta: Erlangga.

[52] Rahmat, Jalaludin. 2012. Modern Rhetoric: Practical Approach. Bandung: PT Remaja Rosdakarya.

[53] Rizam, Masyithah Maghfirah. 2015. Reasoning in Opinion Rubric Article of Daily Jawa Pos Newspaper. Downloaded From http://ejournal.umm.ac.id/index.php/kembara/article/viewFi le/2616/3267 on Sunday, July 1, 2018

[54] Rizqiya, Ita Anis. 2016. The Asking Rhetoric Strategy of Najwa Shihab in "Mata Najwa" Show in Metro TV . Downloaded from http://repository.unej.ac.id/bitstream/han dle/123456789/76076/Anis\%20Ita\%20Riaqiyah\%20-\%201 20210402095\%20-1.pdf?sequence+1 on Sunday, July 1, 2018

[55] Rofi'uddin, Ahmad. 1990. The Study About The Form and Function of Questions in The Interaction of Indonesian Language Class and in Family Interaction. Dissertation. Malang: IKIP Malang.

[56] Rogers, Natalie. 2003. How to Speak Without Fear: Kaushal Goyal for GoylSaab. Bandung: Nuansa Cendekia.

[57] Samsuri. 1985. Sentence Structure of Indonesian Language. Jakarta: Hudaya Literature.

[58] Schiffrin, Deborah. 2007. The Design of Passage Study. Yogyakarta: Learners’ Library

[59] Smith, Donald K. 1969. Man Speaking A Rhetorich Of Public Speech New Jersey; Dodd Mead.

[60] Suhandang, Kustadi, 2009, Rhetoric: Strategy, Technique, and Tactics of Speech, Jakarta Nuansa.
[61] Suparno and Yunus, Mohamad. 2004. Basci Writing Skill. Jakarta: Universitas Terbuka

[62] Suparno, dkk. 2007. Speaking. Jakarta: Open University

[63] Supratman, Dandan. 1982. Measuring Speaking Skill. Media: Journal of Teaching Faculty and Art Literature IKIP

[64] Susandi. 2011. Rhetoric: An Introduction. Malang: Indus Nesus Publishing.

[65] Stanley, Linda, C etall (1988) Ways to Writing. Purpose, Task, and Process. New York: Macmillan Publishing Company.

[66] Syafi'ie, Imam. 1988. Rhetoric in Writing. Jakarta: Education and Culture Department.

[67] Syafi'i, Imam. 1988. Rhetoric in Writing. Jakarta: Directorate General of Higher Education. Depdiknas.

[68] Tarigan, Henry Guntur. 1983. Writing as Certain Language Skill. Bandung: Angkasa.

[69] Tarigan, Henry Guntur. 1986. The Teaching of Language Style. Bandung: Angkasa

[70] Toulmin, Stephen, Richard Rieke and Allan Janik. 1979. An Introduction to Reasoning. Canada: Macmilllan Publishing Company.

[71] Tarigan, Henry Guntur. 2008. Speaking as Certain Language Skill. Bandung: Angkasa.

[72] Wellek, Rene dan Warren, Austin. 1989. Theory of Literature. Jakarta: PT. Gramedia.

[73] Wijana, I Dea Putu. 1996. Basics of Pragmatics. Yogyakarta: Andi.

[74] Yule, George. 1996. Pragmatics. Yogyakarta: Pustaka Pelajar

[75] Zaenal, Yusuf. 2013. Introduction to Rhetoric. Bandung: CV Pustaka Setia

[76] Saldaria. Dkk. 2019. Speaking skill of elementary school students reviewed by gender https://journal.uny.ac.id/index. php/jpe/article/view/20363/pdfDOI: https://doi.org/10.21831/jpe.v7i1.20363

[77] Burnette, A. Review of Argumentation in Actual Practice: Topical Studies About Argumentative Discourse in Context, eds. Frans H. van Eemeren and Bart Garssen. Argumentation (2020). https://doi.org/10.1007/s10503-020-09539-7

[78] Plantin, C. Argumentation Through Languages and Cultures. Argumentation (2020). https://doi.org/10.1007/s10503-02009529-9

[79] Wintgens, L.J. Rhetoric, reasonableness and ethics: An essay on Perelman. Argumentation 7, 451-460 (1993). https://doi.org/10.1007/BF00711061

[80] Kock, C. Introduction: Rhetoricians on Argumentation. Argumentation 34, 287-295 (2020). https://doi.org/10.1007 /s10503-019-09503-0

[81] Danisch, R. Rhetorical Structures, Deliberative Ecologies, and the Conditions for Democratic Argumentation. Argumentation 34, 339-353 (2020). https://doi.org/10.100 7/s10503-019-09496-w 